\title{
Obstetric and perinatal outcome of twin pregnancy: a prospective study in a tertiary care hospital in North India
}

\author{
Shivali Bhalla ${ }^{1 *}$, Seema Grover Bhatti ${ }^{1}$, Shalini Devgan ${ }^{2}$
}

\begin{abstract}
${ }^{1}$ Department of Obstetrics and Gynecology, ${ }^{2}$ Department of Community Medicine, Guru Gobind Singh Medical College and Hospital, Faridkot, Punjab, India
\end{abstract}

Received: 14 April 2018

Accepted: 08 May 2018

\section{*Correspondence:}

Dr. Shivali Bhalla,

E-mail: manasmansha@gmail.com

Copyright: (c) the author(s), publisher and licensee Medip Academy. This is an open-access article distributed under the terms of the Creative Commons Attribution Non-Commercial License, which permits unrestricted non-commercial use, distribution, and reproduction in any medium, provided the original work is properly cited.

\begin{abstract}
Background: Multiple pregnancy constitutes an important portion of high risk pregnancies and is a matter of grave concern to obstetricians and paediatricians owing to maternal and perinatal morbidity and mortality associated to it. Objective of present study was to evaluate maternal and perinatal outcome of twin pregnancy.

Methods: This observational study included 50 women with twin pregnancy with gestational age of 26 weeks or more. Maternal and perinatal outcomes were studied.

Results: The incidence of twin pregnancy was $2.8 \%$ with maximum incidence in age group of $20-29$ years and in multigravida. Mean gestational age was 34.2 weeks. Vertex - vertex fetal presentation was most common presentation. Most frequent mode of delivery was ceserean section (54\%). Preterm labour was most common maternal complication (74\%), followed by anaemia (62\%). Complications in perinatal period were birth hypoxia (58 $\%)$, intrauterine growth restriction (15\%), hyper-bilirubinemia (11\%) and neonatal sepsis $(10 \%)$. 88\% of the newborns were LBW. Perinatal mortality in our study was $17 \%$.

Conclusions: Twin pregnancies are associated with significant maternal and perinatal morbidity which is more so for second twin. Effective antenatal care planned delivery and good pediatric facilities help decrease the complications. Managment of twin pregnancy requires multidisciplinary approach and involvement of skilled obstetricians and paediatricians.
\end{abstract}

Keywords: Maternal morbidity, Preterm birth, Perinatal morbidity, Twin pregnancy

\section{INTRODUCTION}

Multiple pregnancy constitutes an important portion of high risk pregnancies and is a matter of grave concern to obstetricians and paediatricians owing to maternal and perinatal morbidity and mortality associated to it.

Twin pregnancies have increased rates of complications such as preeclampsia, antepartum and post-partum haemorrhage, anaemia, polyhydramnios, increased rate of ceserean section and preterm birth as compared to singleton pregnancies. $^{1-4}$ In addition, these pregnancies are prone to complications exclusive to twinning like twin-twin transfusion syndrome, acardiac twins and conjoint twins. The worldwide incidence of multiple pregnancies varies around 2-20 per 1000 births. ${ }^{5}$ Highest burden of multiple pregnancies is seen in Sub-Saharan Africa, with average twinning rate of 20 per 1,000 deliveries as compared to 10 per 1,000 deliveries in Europe and around 5-6 per 1,000 deliveries in Asia. ${ }^{6-8}$ Since 1980 , there has been $65 \%$ increase in the frequency of twins and a $500 \%$ increase in triplet and higher order births. $^{9}$ The incidence of multiple pregnancies is increasing dramatically over a past few years owing to trend among women towards late childbearing and widespread use of assisted reproduction techniques. The 
objective of this study was to evaluate the feto-maternal outcome of twin pregnancies at our hospital.

\section{METHODS}

This prospective observational study was conducted in the department of Obstetrics and Gynaecology of the hospital for a period of one year, between January 2017 to December 2017.Women with twin pregnancy with gestational age of 26 weeks or more admitted and delivered in the maternity ward of our hospital during the study period were included in the study. Patients discharged after taking conservative management were excluded from study. Twins requiring admissions in neonatal units were also followed up to their discharge. Detailed history of patients and their chief complaints was recorded. Age, parity, gestational age, menstrual history, obstetric histories were noted along with family history of multiple pregnancies if any. History of ovulation induction drugs /In Vitro fertilization (IVF) was asked. Obstetric complications like Pregnancy induced hypertension, anaemia, preterm labour, Intrauterine growth restriction, Premature rupture of membranes were studied.

Number of patients who delivered spontaneously vaginally, those requiring instrumentation and also those who required caesarean section was recorded. Fetal outcome, gestational age at birth, weight at birth, APGAR scores and requirement for NICU admission were analyzed. The statistical data was then analysed using SPSS 20. Variables studied were reported as the mean, range and standard deviation (SD). $P$ values of $<0.05$ were considered to indicate statistically significant. The study was ethically conducted in accordance with Declaration of Helsinki.

\section{RESULTS}

Out of the total 1768 antenatal patients delivered during the year 2017 in our hospital, 51 patients presented with multiple pregnancy.

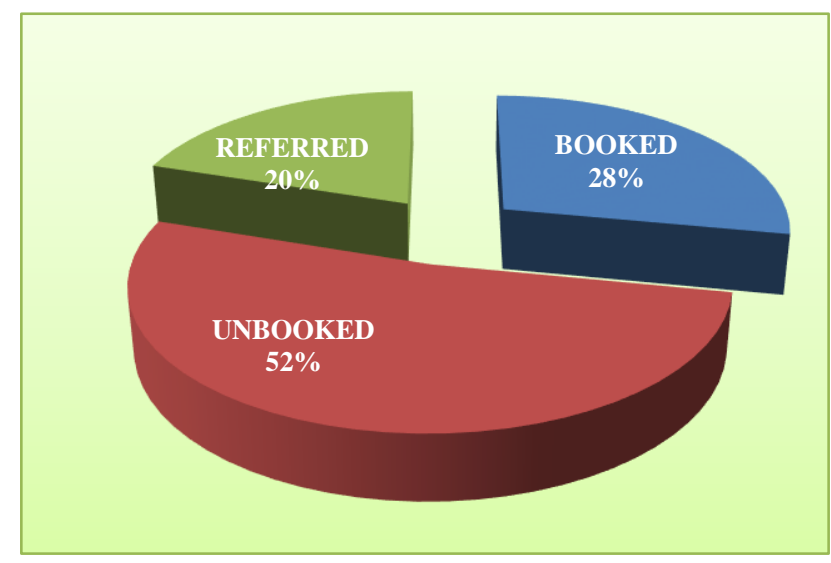

Figure 1: Incidence of multiple pregnancy according to booking status.
Of these, one had triplet pregnancy and was excluded from our study and rest 50 were cases of twin pregnancy. The incidence of twin pregnancy in our study was $2.8 \%$. Fifty -two percent patients were un-booked, 20\% referred from peripheral centres and rest were booked (Figure 1).

Table 1: Demographic and obstetric profile of the patients $(\mathbf{n}=\mathbf{5 0})$.

\begin{tabular}{|lll|}
\hline Parameter & Number & Percentage \\
\hline Age & & \\
\hline$<20$ yrs & 7 & 14 \\
\hline$\leq 20-29$ yrs & 28 & 56 \\
\hline$\geq 30$ yrs & 15 & 30 \\
\hline Parity & & \\
\hline primipara & 9 & 18 \\
\hline multipara & 41 & 82 \\
\hline Gestational age & at delivery) & \\
\hline$\geq 26-<30$ wks & 3 & 6 \\
\hline$\geq 30-<34$ wks & 23 & 46 \\
\hline$\geq 34-<38$ wks & 19 & 38 \\
\hline$\geq 38$ wks & 5 & 10 \\
\hline
\end{tabular}

Mean maternal age of the patients in our study was 27.3 years (SD: 5.136; Range 18-38). Fifty-six percent patients were aged between $20-29$ years. Parity distribution of the patients showed $82 \%$ multipara and $18 \%$ primipara. The mean gestational age at delivery was 34.2 weeks (SD: 2.6; Range 28-40) (Table 1).

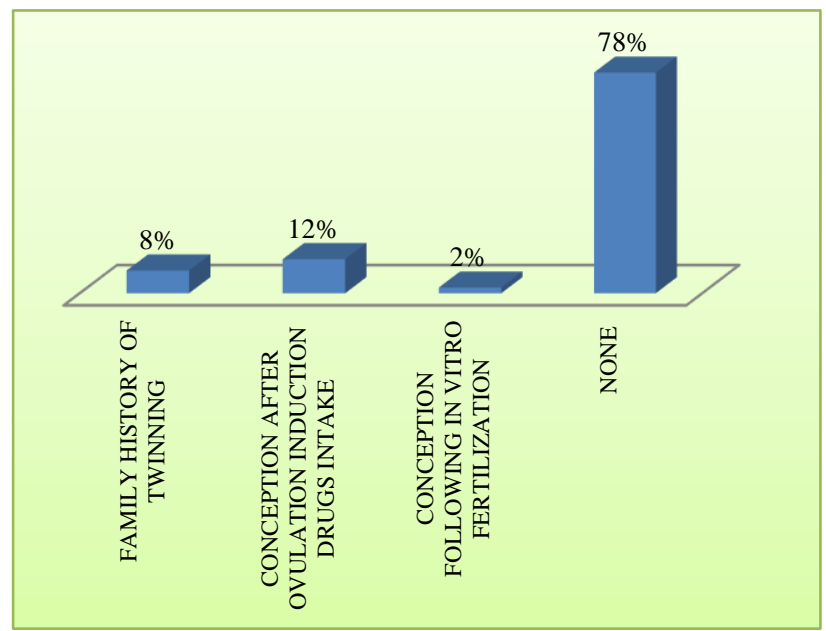

Figure 2: Probable causative factors for twinning.

Underlying probable causative factor for twinning was revealed to be conception after intake of ovulation induction drugs in $12 \%$ women. history of twinning was present in $8 \%$ women. One woman had conceived following IVF (Figure 2).

With respect to chorionicity, $60 \%$ of women were dichorinic. Fourteen percent were monochorionic diamniotic and $6 \%$ patients were monochorionicmonoamniotic. Chorionicity was unknown in $20 \%$ cases (Figure 3). 


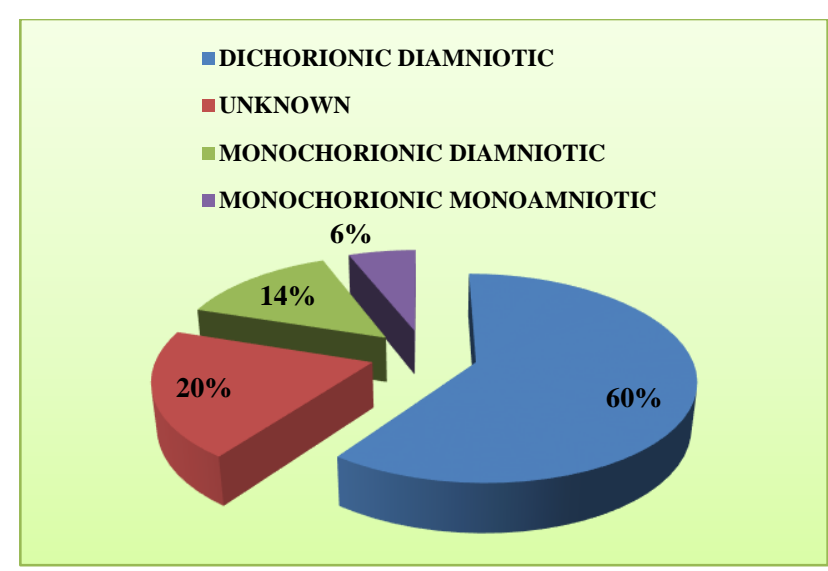

Figure 3: Distribution of patients by type of chorionicity.

Vertex - vertex $(\mathrm{Vx}-\mathrm{Vx})$ fetal presentation was most common presentation at delivery (52\% patients) followed by Breech -vertex (B-Vx) in $18 \%$ women (Figure 4$)$.

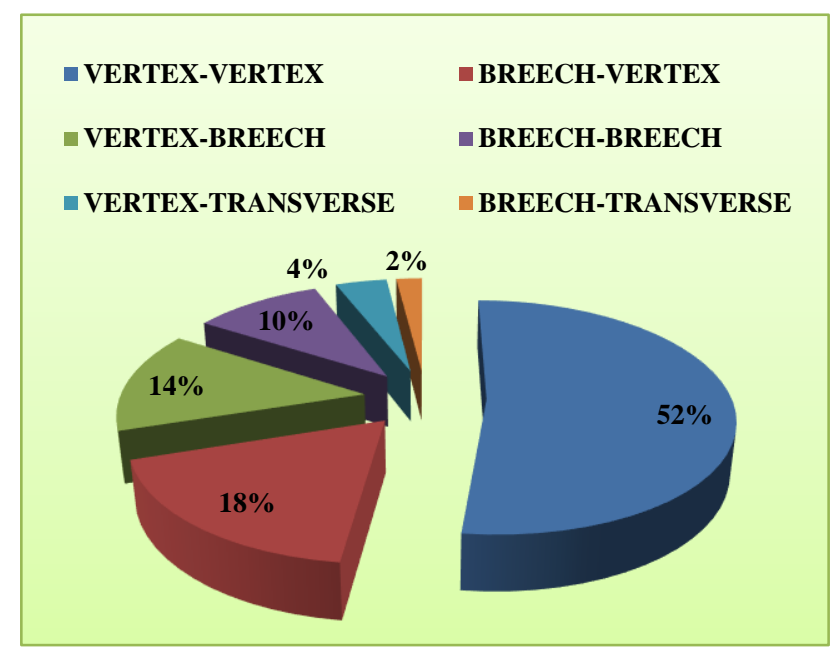

Figure 4: Distribution of patients by fetal presentation.

The most frequent mode of delivery was ceserean section (54\%). Malpresentation and history of previous ceserean section were the main indications for ceserean delivery in our study ( $48 \%$ and $22.2 \%$ respectively). Spontaneous delivery was observed only in $36 \%$ patients. Delivery interval between $1^{\text {st }}$ and $2^{\text {nd }}$ twin was $<15 \mathrm{~min}$ in $78 \%$ cases (Table 2).

Preterm labour was the most common maternal complication of twin pregnancy (74\% patients), followed by anaemia, encountered in, $62 \%$ cases. Thirty percent cases were complicated by pregnancy induced hypertension. One patient had post partum eclampsia and accounted for near miss mortality case in our study. Twenty-four percent patients had premature rupture of membranes. Antepartum haemorrhage and post partum haemorrhage complicated $16 \%$ and $18 \%$ cases respectively.
Table 2: Distribution of patients by mode of delivery, delivery interval $b / w 1^{\text {st }}$ and $2^{\text {nd }}$ twin and indication of ceserean section in twin pregnancy $(\mathrm{N}=50)$.

\begin{tabular}{|lll|}
\hline $\begin{array}{l}\text { Parameter studied } \\
\text { Mode of delivery }\end{array}$ & Number & Percentage \\
\hline Spontaneous & 18 & 36 \\
\hline Assisted Breech & 4 & 8 \\
\hline Instrumental & 1 & 2 \\
\hline LSCS & 27 & 54 \\
\hline Delivery interval b/w $1^{\text {st }}$ & and $2^{\text {nd }}$ & twin \\
\hline$<15$ min & 39 & 78 \\
\hline 15-30 min & 10 & 20 \\
\hline $31-60$ min & 1 & 2 \\
\hline $\begin{array}{l}\text { Indication of LSCS in twin pregnancy } \\
\text { (N=27) }\end{array}$ & 54 \\
\hline Mal presentation & 13 & 48.14 \\
\hline Previous LSCS & 6 & 22.22 \\
\hline Fetal distress & 3 & 11.11 \\
\hline PIH & 1 & 3.70 \\
\hline Non progress of labor & 2 & 7.40 \\
\hline APH & 2 & 7.40 \\
\hline
\end{tabular}

There was no maternal mortality in the study. One of the patient with monochorionic twin pregnancy presented with Twin -Twin Transfusion Syndrome and one patient with dichorionic twin pregnancy had single Intrauterine Fetal Demise (sIUFD) at 1st trimester and delivered in 3rd trimester, one healthy fetus and other dead fetus weighing $304 \mathrm{gm}$ (Table 3 and 4).

Table 3: Antenatal complications encountered among patients $(\mathbf{n}=\mathbf{5 0})$.

\begin{tabular}{|lll|}
\hline Complication & Number & Percentage \\
\hline Anaemia & 31 & 62 \\
\hline Hyperemesis Gravidarum & 4 & 8 \\
\hline $\begin{array}{l}\text { Hypertension (PIH/Pre } \\
\text { eclampsia/eclampsia ) }\end{array}$ & 15 & 30 \\
\hline Polyhydramnios & 3 & 6 \\
\hline $\begin{array}{l}\text { APH (abruption, placenta } \\
\text { previa) }\end{array}$ & 8 & 16 \\
\hline PROM & 12 & 24 \\
\hline UTI & 3 & 6 \\
\hline Gestational diabetes & 2 & 4 \\
\hline No associated complications & 7 & 14 \\
\hline Complications inherent to twinning & \\
\hline TTTS & 1 & 2 \\
\hline TRAP & - & - \\
\hline sIUFD & 1 & 2 \\
\hline
\end{tabular}

(Note:- Some patients had more than one complication, as such total will not correspond to $100 \%$ )

The common complications seen in the perinatal period were birth hypoxia /respiratory distress syndrome (58\%), intrauterine growth restriction (15\%), hyperbilirubinemia (11\%) and neonatal sepsis (10\%) (Table 5). 
Table 4: Intrapartum maternal complications encountered among patients $(n=50)$.

\begin{tabular}{|lll|}
\hline Complication & Number & Percentage \\
\hline Preterm Labour & 37 & 74 \\
\hline PPH & 9 & 18 \\
\hline Sepsis & 1 & 2 \\
\hline Preterm LSCS & 10 & 20 \\
\hline Tears & 14 & 28 \\
\hline Post partum eclampsia & 1 & 2 \\
\hline No complication & 0 & 0 \\
\hline
\end{tabular}

(Note:- Some patients had more than one complication, as such total will not correspond to $100 \%$ )

Table 5: Causes of perinatal morbidity $(n=100)$.

\begin{tabular}{|lll|}
\hline Morbid condition & Number & Percentage \\
\hline Prematurity & 70 & 70 \\
\hline Birth weight & & \\
\hline$<1 \mathrm{~kg}$ & 10 & 10 \\
\hline $1-1.5 \mathrm{~kg}$ & 40 & 40 \\
\hline $1.6-2.5 \mathrm{~kg}$ & 38 & 38 \\
\hline$>2.5 \mathrm{~kg}$ & 12 & 12 \\
\hline IUGR & 15 & 15 \\
\hline Birth asphyxia /hypoxia/RDS & 58 & 58 \\
\hline Septicemia & 10 & 10 \\
\hline Jaundice & 11 & 11 \\
\hline Anaemia & 15 & 15 \\
\hline Congenital malformations & 6 & 6 \\
\hline
\end{tabular}

The incidence of these perinatal complications was found to be more among the second coming twins than their first coming counterparts. Low birth weight (LBW) in our study was defined as birth weight of $<2.5 \mathrm{~kg}$ and $88 \%$ of the newborns were LBW.

Table 6: Comparison of birth weights of first of the coming twin (TWIN 1) and second of the coming twin (TWIN 2).

\begin{tabular}{|lll|}
\hline Parameter & Twin 1 & Twin 2 \\
$\begin{array}{l}\text { Mean birth weight } \\
(\mathrm{gm})\end{array}$ & 1898gm & 1560gm \\
\hline $\begin{array}{l}\text { Standard deviation } \\
\text { (SD) }\end{array}$ & 0.5505 & 0.5686 \\
\hline
\end{tabular}

Using unpaired $\mathrm{T}$ test to find out whether there is significant difference in the weights between first and second twin we found the results statistically highly significant with $\mathrm{P}$ value $<0.003$.

The second coming twins were found to have lower birth weights than the first coming twins. The mean birth weight of first coming twins (TWIN 1) was 1898 gm; SD: 0.5505 and that of second coming twins (TWIN 2) was 1560 gm SD:0.5686. Using unpaired $\mathrm{T}$ test to find out whether there is significant difference in the weights between first and second twin we found the results statistically highly significant with $\mathrm{P}$ value $<0.003$ (Table 6).

Table 7: Comparison of incidence of birth hypoxia/asphyxia amongst first of the coming twins (Twin 1) and second of the coming twins (Twin 2).

\begin{tabular}{|c|c|c|c|c|c|c|}
\hline \multirow{2}{*}{ Birth hypoxia } & \multirow{2}{*}{ Twin 1 (T1) $\mathbf{N}$} & \multirow{2}{*}{$\begin{array}{l}\text { Twin (T1) } \\
\%\end{array}$} & \multirow{2}{*}{ Twin 2 (T2) $\mathbf{N}$} & \multirow{2}{*}{$\begin{array}{l}\text { Twin } 2 \text { (T2) } \\
\%\end{array}$} & \multicolumn{2}{|l|}{ Total } \\
\hline & & & & & $\mathbf{N}(\mathbf{T} 1+\mathbf{T} 2)$ & Percentage \\
\hline Present & 20 & 34.5 & 38 & 65.5 & 58 & 58 \\
\hline Absent & 30 & 71.4 & 12 & 28.6 & 42 & 42 \\
\hline Total & 50 & & 50 & & 100 & 100 \\
\hline
\end{tabular}

This difference in incidence of birth asphyxia was highly significant with Chi square value of 13.3 and $\mathrm{P}$ value of 0.0002

Table 8: Comparison of Apgar scores between the first and second coming twins.

\begin{tabular}{|c|c|c|c|c|c|c|}
\hline APGAR scores & Twin 1 (T1) & Twin 1 (T1) & Twin 2 (T2) & Twin 2 (T2) & Total & \\
\hline & $\mathbf{N}$ & $\%$ & $\mathbf{N}$ & $\%$ & $\mathbf{N}(\mathbf{T} 1+\mathbf{T} 2)$ & $\%$ \\
\hline$<7$ at $1 \mathrm{~min}$ & 14 & 41.2 & 20 & 58.8 & 34 & 34 \\
\hline$>7$ at $1 \mathrm{~min}$ & 36 & 54.5 & 30 & 45.5 & 66 & 66 \\
\hline & 50 & & 50 & & 100 & 100 \\
\hline
\end{tabular}

Chi square value $=1.6 ; \mathrm{P}$ value $=0.205$ (not significant)

Also, the incidence of birth hypoxia /respiratory distress syndrome was found to be significantly higher among second coming twins $(65.5 \%)$ than first coming twins $(34.5 \%)$ (chi square value of 13.3 and $P$ value of 0.0002 ) (Table 7). APGAR score of $<7$ at 1 min was seen in $34 \%$ newborns. Apgar score $<7$ at $1 \mathrm{~min}$ was reported in $41.2 \%$ of first coming twins and $58.8 \%$ of second coming twins. However, this difference in APGAR scores was not statistically significant (Chi square value $=$ 1.6; $\mathrm{P}$ value $=0.2$ ) $($ Table 8$)$. NICU admission was required in $66 \%$ of all neonates, (TWIN 1: $45.45 \%$; TWIN 2: $54.55 \%$ ). However, this difference amongst first and second coming twins was not statistically significant (Chi square value <0.84) (Table 9). 
Table 9: Comparison of requirement of NICU among first of the coming twins (TWIN 1) and second of the coming twins (TWIN 2).

\begin{tabular}{|c|c|c|c|c|c|c|}
\hline \multirow{2}{*}{ NICU requirement } & \multirow{2}{*}{ Twin $1 \mathrm{~N}$} & \multirow{2}{*}{ Twin 1\% } & \multirow{2}{*}{ Twin $2 \mathbf{N}$} & \multirow{2}{*}{ Twin $2 \%$} & \multicolumn{2}{|l|}{ Total } \\
\hline & & & & & $\mathbf{N}(\mathbf{T} 1+\mathrm{T} 2)$ & $\%$ \\
\hline Required & 30 & 45.45 & 36 & $54.55 \%$ & 66 & 66 \\
\hline Not required & 20 & 58.82 & 14 & $41.18 \%$ & 34 & 34 \\
\hline Total & 50 & & 50 & & & \\
\hline
\end{tabular}

However, this difference amongst twins was not statistically significant (Chi square value $<0.84$

Table 10: Perinatal mortality among twin 1 and twin 2 ( $\mathrm{N}=100$ babies) in relation to mode of delivery.

\begin{tabular}{|c|c|c|c|c|c|c|}
\hline Mode of delivery & $\begin{array}{l}\text { Total No of } \\
\text { patients }\end{array}$ & $\begin{array}{l}\text { Total No } \\
\text { of births }\end{array}$ & $\begin{array}{l}\text { Perinatal } \\
\text { deaths } \\
\text { (TWIN 1) }\end{array}$ & $\begin{array}{l}\text { Perinatal } \\
\text { deaths } \\
\text { (TWIN 2) }\end{array}$ & $\begin{array}{l}\text { Total perinatal } \\
\text { deaths }(\mathrm{T} 1+\mathrm{T} 2)\end{array}$ & $\begin{array}{l}\text { Perinatal } \\
\text { mortality \% }\end{array}$ \\
\hline $\begin{array}{l}\text { Spontaneous } \\
\text { vaginal delivery }\end{array}$ & 18 & 36 & 3 & 6 & 9 & 52.9 \\
\hline $\begin{array}{l}\text { Assisted breech } \\
\text { delivery }\end{array}$ & 4 & 8 & 0 & 1 & 1 & 5.9 \\
\hline $\begin{array}{l}\text { Instrumental } \\
\text { delivery }\end{array}$ & 1 & 2 & 0 & 1 & 1 & 5.9 \\
\hline LSCS & 27 & 54 & 1 & 5 & 6 & 35.3 \\
\hline Total & 50 & 100 & 4 & 13 & 17 & 100 \\
\hline
\end{tabular}

Perinatal mortality in present study was $17 \%$; Chi square value $=0.269 ; \mathrm{P}$ value $=0.622$

Total 50 women gave birth to 95 live births, 4 babies were fresh still born, 1 baby was macerated abortus weighing $304 \mathrm{gm}$. Out of these 12 babies could not survive more than one week owing to complications. Perinatal mortality in our study was $17 \%$ or $170 / 1000$. Highest mortality was associated with instrumental delivery $(50 \%)$ (Table 10). Neonatal outcome is summarized in Table 11. Neonatal morbidity increases as gestational age at delivery decreases.

Table 11: Neonatal outcome $(n=100)$.

\begin{tabular}{|ll|l|}
\hline Parameter & Number & Percentage \\
\hline Live births & 95 & 95 \\
\hline NICU admission & 66 & 66 \\
\hline Neonatal death at $1^{\text {st }}$ wk & 12 & 12 \\
\hline Still birth & & \\
\hline Fresh still born & 4 & 4 \\
\hline Macerated still born & 1 & 1 \\
\hline
\end{tabular}

\section{DISCUSSION}

Twin pregnancies are high risk pregnancies requiring special care and multidisciplinary approach towards their management. The incidence of twin pregnancy in our study was $2.8 \%$ which is quite high in contrast to traditional incidence of $0.2-2 \% .^{5}$ This higher incidence found in our study can be attributed to growing trend towards child bearing at advanced maternal age and disseminated use of Assisted Reproductive Techniques (ART) as $12 \%$ patients in present study had conceived after treatment for infertility with clomiphene citrate and one patient had conceived with IVF .Hence $14 \%$ patients in our study can be labelled as cases of iatrogenic twinning. The same finding was reported in study by Sultana et al where rate of iatrogenic twinning was also $14 \% .{ }^{10}$ Majority of the women in present study (56\%) were aged between $20-29$ years. This is consistent to a study by Spellacy et al where $55 \%$ were aged between 20 -29 years. ${ }^{11}$ Parity distribution of our study showed $82 \%$ patients as multipara which is consistent to report by Spellacy et al where $84.2 \%$ patients were multipara. Mean gestational age of women at delivery in our study was 34.2 weeks. $^{11}$ As compared to other studies, the average weeks of gestation are comparable with our study i.e 34 weeks, as the average weeks of gestation among twins being 33 weeks by Erdemoglu et al and 34 weeks by Yuel et al. ${ }^{12,13}$ Placentation was determined by antenatal ultrasonography and inspection of placenta and membranes after birth. Dichorionic placentation was seen in majority (60\%) in our study, which is comparable with Erdemoglu et al (69.3\%) and Panwala et al (63.8\%). ${ }^{12,14}$ Vertex -vertex (vx-vx) presentation at delivery was most common fetal presentation in present study (52\%) and was to be consistent with another study by Chowdhury et al $(47.5 \%)$ and Panwala et al $(51.4 \%) .{ }^{14,15}$ Most frequent mode of delivery in our study was by lower segment ceserean section (54\%), consistent to studies by Chowdhury and Sultana $(49.1 \%$ and $56 \%$ respectively). ${ }^{10,15}$ Malpresentation was the most common indication for ceserean section in our study $(48.14 \%)$ which is comparable with Erdemoglu et al (46.3\%). ${ }^{12}$ Forty-six percent patients delivered vaginally. Out of these four patients had assisted breech delivery and in one patient forceps delivery was required to deliver the 
after coming head of second breech twin. The delivery interval between first and second twin was $<15$ min in $78 \%$ patients and $<30 \mathrm{~min}$ in $20 \%$ patients. In one patient second twin was delivered 56 minutes after the first twin.

Authors found higher neonatal morbidity in second coming twins especially in cases where the delivery interval between the two twins was $>15 \mathrm{~min}$. From this we conclude that there should be minimum delay in the delivery of second coming twin to prevent post natal complications. Preterm labour was found to be the most common maternal complication in our study seen in $74 \%$ cases. Preterm delivery rate in our study was $70 \%$ and we found a high pre term ceserean section rate of $20 \%$ in present study. This finding is in contrast to previous studies by Papicrnik, Chowdhury and Sultana where preterm delivery rates were $50.7 \%, 41.5 \%$ and $44 \%$ respectively. ${ }^{10,15,16}$ Higher preterm delivery rate in present study could be attributed to higher incidence of associated obstetric and /or medical co-morbidities in our patients, necessitating early delivery. Anaemia was the second most common maternal complication in our study reported in $62 \%$ patients in present study whereas the corresponding figures reported by Chowdhury and Brown et al were $35.8 \%$ and $35.5 \%$ for anaemia. ${ }^{15,17}$ Hence authors reported higher incidence of anemia in our study. However, a much higher incidence of anemia was found by Bangal et al $(84 \%) .{ }^{18}$ This discrepancy in incidence of anaemia may be due to difference in prevalence of anaemia in different regions. Birth hypoxia was reported in $58 \%$ of neonates. The incidence of birth asphyxia was much higher among second coming twins (65.5\%) than first coming twins (34.5\%). Hypertensive disorders (PIH/ Pre-eclampsia / Eclampsia) were reported in $30 \%$ patients in present study. This is higher in comparison to that observed in studies by Bangal et al and by Chowdhury et al where they were observed in $18 \%$ and $22.6 \%$ cases respectively. ${ }^{15,18}$ Post partum haemorrhage occurred in $18 \%$ cases in present study which bears consistency to study by Chowdhury (18.9\%). ${ }^{15}$ Twenty -four percent of the patients were admitted with Premature Rupture of Membranes (PROM). However, Chowdhury and Sultana reported lower rate of PROM for twin pregnancy $(3.8 \%$ and $10 \%$ respectively). ${ }^{15,10}$ Twin Twin Transfusion syndrome was seen in one patient where one baby had polyhydramnios and second baby had Intrauterine growth restriction with oligohydramnios. Both babies of this patient however survived. There was no maternal mortality in present study. Twin pregnancy is known to be associated with significant perinatal morbidity and mortality.

Authors observed perinatal mortality of $17 \%$ in our study which is higher than that found in studies by Chowdhury and Sultana et al. ${ }^{10,15}$ Authors observed higher perinatal mortality among unbooked patients and patients referred from periphery $(21.42 \%)$ in comparison to booked patients (15.2\%) which reflects importance of proper antental care for better feto -maternal prognosis in twin pregnancies. The incidence of stillbirth in our study was
$5 \%$. Sixty - six percent of the neonates required NICU admission owing to neonatal morbidity. Low birth weight and prematurity were the leading causes for perinatal morbidity in our study ( $88 \%$ and $70 \%$ respectively) followed by birth hypoxia in $58 \%$ babies. The incidence of congenital malformations in present study was $6 \%$. One case each of lumbar mengiomyelocele, hydrocephalus and omphalocele and 2 cases of ventricular septal defets was seen. In one case, $2^{\text {nd }}$ delivering twin, had talipo equino varus deformity owing to oligohydramnios. It is a well known fact that the second of the coming twins is usually more compromised than the first of the coming twins. The same was observed in present study also. Neonatal parameters like birth weights, APGAR scores, incidence of birth asphyxia and NICU requirement were compared amongst first coming and second coming twins and the results were analysed statistically by Unpaired $\mathrm{T}$ test and Chi square test. Birth weight discrepancy of $20 \%$ or more than it was considered as significant discordant growth in our study. The incidence of discordant growth in our study was $30 \%$ (15 pairs). APGAR score of $<7$ at $1 \mathrm{~min}$ was observed in $34 \%$ all babies. Of this, the incidence of 1 min APGAR $<7$ among Twin 1 babies was $41.2 \%$ and among twin 2 babies was $58.8 \%$, showing that low APGAR score was more common amongst the second of the twins as compared to first of the twins in present study. However, this difference in APGAR scores between the two groups was not significant statistically with Chi square value of 1.6 and $P$ value of 0.205 . This may be attributes to the fact that our study included small sample size of 50 patients and also to the high ceserean section rate in present study which decreased the delivery time interval between the first and the second twins, leading to lesser difference in $1 \mathrm{~min}$ APGAR scores among the twins. The incidence of birth asphyxia in our study was $58 \%$. The incidence of asphyxia amongst second of the coming twins was more $(\mathrm{N}=38 ; 65.5 \%)$ in comparison to first of the coming twins $(\mathrm{N}=20 ; 34.5 \%)$ and was highly significant with Chi square value of 13.3 and $P$ value of 0.0002 . NICU requirement was in $66 \%$ of the babies owing to neonatal morbidities. Of these 30 of the first coming twins $(45.45 \%)$ and 36 of the second twins $(54.55 \%)$ required NICU admission.

Low birth weight and prematurity are known leading causes of perinatal morbidity and mortality. The incidence of birth hypoxia, perinatal deaths and NICU requirement increases as gestational age at delivery decreases. The same was noted in present study.

\section{CONCLUSION}

Multiple pregnancies are associated with higher maternal and fetal/neonatal adverse outcomes. Early detection of high risk cases, timely referral, frequent antenatal visits and early hospitalization with good neonatal care set up are necessary to improve maternal and neonatal outcomes. 


\section{ACKNOWLEDGMENT}

Authors would like to thank Dr. Mandeep Kumar Tiwary for his support.

Funding: No funding sources Conflict of interest: None declared

Ethical approval: Not required

\section{REFERENCES}

1. Smits J, Monden C. Twinning across the developing world. PLoS One. 2011 Sep 28;6(9):e25239.

2. Sumathipala A, Siribaddana S, De Silva N, Fernando D, Abeysingha N, Dayaratne R, De Silva D, Warnasuriya N, Hotopf M. Sri Lankan twin registry. Twin Research and Human Genetics. 2002 Oct;5(5):424-6.

3. Aisien AO, Olarewaju RS, Imade GE. Twins in Jos Nigeria: a seven-year retrospective study. Med Sci Monit. 2000;6:945-50.

4. Obiechina N, Okolie V, Eleje G. Twin versus singleton pregnancies: the incidence, pregnancy complications, and obstetric outcomes in a Nigerian tertiary hospital. Int J Womens Health. 2011;3:227.

5. Doris MC. Multiple pregnancy. Baillieres Clin Obstet Gynaecol. 1990;4:109-27.

6. Bortolus R, Parazzini F, Chatenoud L, Benzi G, Bianchi MM, Marini A, The epidemiology of multiple births. Hum Reprod Update. 1999;5(2):17987.

7. Goetghebuer T, Ota MO, Kebbeh B, John M, Jackson Sillah D, Vekemans J et al. Delay in motor development of twins in Africa: a prospective cohort study. Twin Res. 2003;6(4):279-84.

8. Hoekstra C, Zhao ZZ, Lambalk CB, Willemsen G, Martin NG, Boomsma DI et al. Dizygotic twinning. Hum Reprod Update. 2008;14(1):37-47.
9. Martin JA, Hamilton BE, Sutton PD, Ventura SJ, Menacker F, Munson ML. Births: Final data for 2002. Natl Vital Stat Rep. 2003;52(10):1-102.

10. Sultana H. Fetal and maternal outcome of twin pregnancy-A study of 50 cases. Bangladesh college of Physicians and Surgeons, Dhaka. 1998.

11. Spellacy WN, Handler A, Ferre CD. A case control study of 1253 twin pregnancies from 1982-1987. Perinatal Data Base. 1990;75:198-71.

12. Erdemoglu M, Kale A, Akdeniz N, Yalinkaya A, Ozcan Y. Retrospective analysis of multiple pregnancies. Perinatal Journal. 2005;13(4).

13. Irene $\mathrm{YV}$, Vaneet $\mathrm{K}$. An analytical study of pregnancy outcome in multifetal gestation. J Obstet Gynecol India. 2007 Nov;57(6):509-12.

14. Panwala NM, Mondkar AM, Ranade VR, Purandare VN. Multiple pregnancy. A review of 116 cases. J Postgrad med. 1972 Jul;18(3):108-114.

15. Chowdhury S. Clinical Study on twin pregnancy, FCPS. Bangladesh College of Physicians and Surgeons, Dhaka, 1998.

16. Papiernik E, Keith L, Oleszczuk JJ, Cervantes A. What interventions are useful in reducing the rate of preterm delivery in twins? In: Clinical Obstet and Gynecol. 1998:13-22.

17. Brown EJ, Dixon HG. Twin pregnancy. J Obstet Gynaecol Br Common. 1963;70:251.

18. Bangal VB, Patel SM, Khairnar DN. Study of maternal and foetal outcome in twin gestation at tertiary care teaching hospital. IJBAR. 2012;3(10):758.

Cite this article as: Bhalla S, Bhatti SG, Devgan S. Obstetric and perinatal outcome of twin pregnancy: a prospective study in a tertiary care hospital in North India. Int J Reprod Contracept Obstet Gynecol 2018;7:2455-61. 